\title{
FUNDRAISING FOR UNIVERSITIES BY ALUMNI EFFORTS: A LITERATURE REVIEW
}

\author{
Laila Kundzina $^{1}$, Mg. hist., Baiba Rivza ${ }^{2}$, Prof. Dr. oec.
}

\begin{abstract}
Higher education is co-financed by the state, municipalities, as well as various local and international funds, but the support of individuals and businesses, known as patronage, is playing an increasingly important part. Here, the contributions of alumni are of a great consequence, ranging from cash donations, in-kind donations, volunteering and pro bono contributions. To receive these diverse donations, universities must work diligently on their communications strategy with alumni, current and potential patrons. This strategy should be diversified on the basis of age, gender and wealth. Successful fundraising campaigns are based on a well-thoughtout and ad hoc approach, where each participant clearly understands the goals and objectives of his or her activities.
\end{abstract}

Keywords: philanthropy, university, fundraising, donations, alumni.

JEL code: $A 10, A 20, B 10$

\section{Introduction}

Many governments are decreasing the funding for university research projects. However, with reduced public funding, universities are still expected to deliver excellent research results. Although tuition fees are increased step by step, this cannot be justified with the quality of university performance (Deloitte, 2016). Universities need to move forward in order to be fully competitive. Consequently, it is important to increase involvement of private sector in university development and it is a task of philanthropy (Cutlip, 1990), - to increase the amount and number of private and corporate donations for various university projects. At the same time, it is important to discuss the factors influencing the behaviour of patrons (Brittingham, 1990), the successful philanthropy strategy (Johnstone, 2016), and the institutional development of universities (Kozobarich, 2000).

College and university graduates have an increasingly important part in supporting higher education (Weerts, Cabrera, Sanford, 2010). In 2007, US colleges and universities attracted and received 29 billion in donations, $28 \%$ of which were donated by alumni (Council for Aid to Education, 2008). As government funding continues to decline, leveraging donations from other resources is becoming progressively critical, therefore data collection and researching careers of alumni after graduation is vital (Burke, 1988; Caboni and Proper, 2008).

The objective of the current study is to examine the literature available on fundraising from alumni and models of alumni collaboration with universities. The main task of research is to provide tactics of fundraising from alumni based on Foundation of the University of Latvia case study.

Research hypotheses are: (1) Motivated university alumni are good partners of any university in successful fundraising and attracting prospective students; (2) Universities should develop wellconsidered models of cooperation with alumni, offering them a variety of collaboration opportunities; (3) Universities should take into account the gender, marital status, income and social status of alumni, when establishing partnership and launching fundraising campaigns; (4) Universities should focus their fundraising activities not only on alumni, but also on university staff and representatives of public who are loyal to university.

The study has been carried out using qualitative research methods such as logical constructive method, analysis and synthesis method and monographic method. The study is based on scientific papers and theoretical literature. 


\section{Research results and discussion}

The administrative and academic leaders of colleges and universities must invest efforts in fundraising. Since state support is inadequate, it can be frequently observed that many families cannot afford to secure tertiary education for their children. Informing the current students in timely manner about the importance of alumni donations is crucial. Those students who themselves have received donor support through scholarships and funding of research projects, subsequently become more aware of the decisive character and necessity of their personal donation. Alumni have various opportunities to support their alma mater. They can become ambassadors lobbying for the needs of higher education institutions at national and/or local government level. They can become volunteers who devote their free time to one of the university's events by organizing it or contributing the socalled in-kind donations. For example, by supplying food to participants or providing the musical entertainment for the event. It is a common in-kind donation practice of graduates to purchase books for the university's library. Alumni can also contribute to their university their volunteer work, serving as guides to pupils and their parents on excursions, encouraging them to learn about university's history and achievements, encouraging pupils to consider this university as their next place of studies (Weerts, Cabrera, Sanford, 2010).

Beyond donating funds, alumni can become lobbyists for their university. This tendency assumes an increasingly assertive and widespread character (Potter, 2003). Through various advisory committees, university graduates help their universities and their management to formulate and fulfil their strategic goals (Weerts, 1998). There is also the practice of senior alumni becoming mentors to junior graduates, thus helping them to integrate into the labour market and also providing advice on how to better support their university. This collaboration is definitely more effective than posting job advertisements (Fogg, 2008). The diversity of graduate assistance to their universities is assuming an increasingly notable position with an increase of competition among universities (Cabrera et al., 2005). Building collaborative models and relationships with alumni becomes crucial, hence universities are investing more and more in building these relationships. For example, in 2003, universities in the United States invested 8.7 million USD in activities aimed at collaborating with alumni - the equivalent to the costs of 81 full-time employees (Alumni Relations Task Force, 2004).

Graduates as volunteers are a very generous resource. Volunteering was usually associated with religiosity until faith-based organizations introduced various formal mechanisms to organize volunteering (Penner, 2002). Students should be offered opportunities for volunteering that are geared to the needs of the faculty and/or the university. Students who have volunteered 6 hours or more per week have been shown to be happy to continue this contribution after graduation (Astin et al., 1999). Behavioural patterns of collaboration with one's university are formed before a person commences to attend university. They are based on family values, experiences at primary and secondary school, various youth activities and the values of the community. The importance of social exchange theory in understanding the potential contribution of alumni in supporting their own universities must be appreciated (Weerts and Ronca, 2008).

Firstly, social exchange theory requires relationships to be shaped according to "give and take" principle and sometimes these relationships strike an uneven balance between partners. 


\section{Social exchange theory}

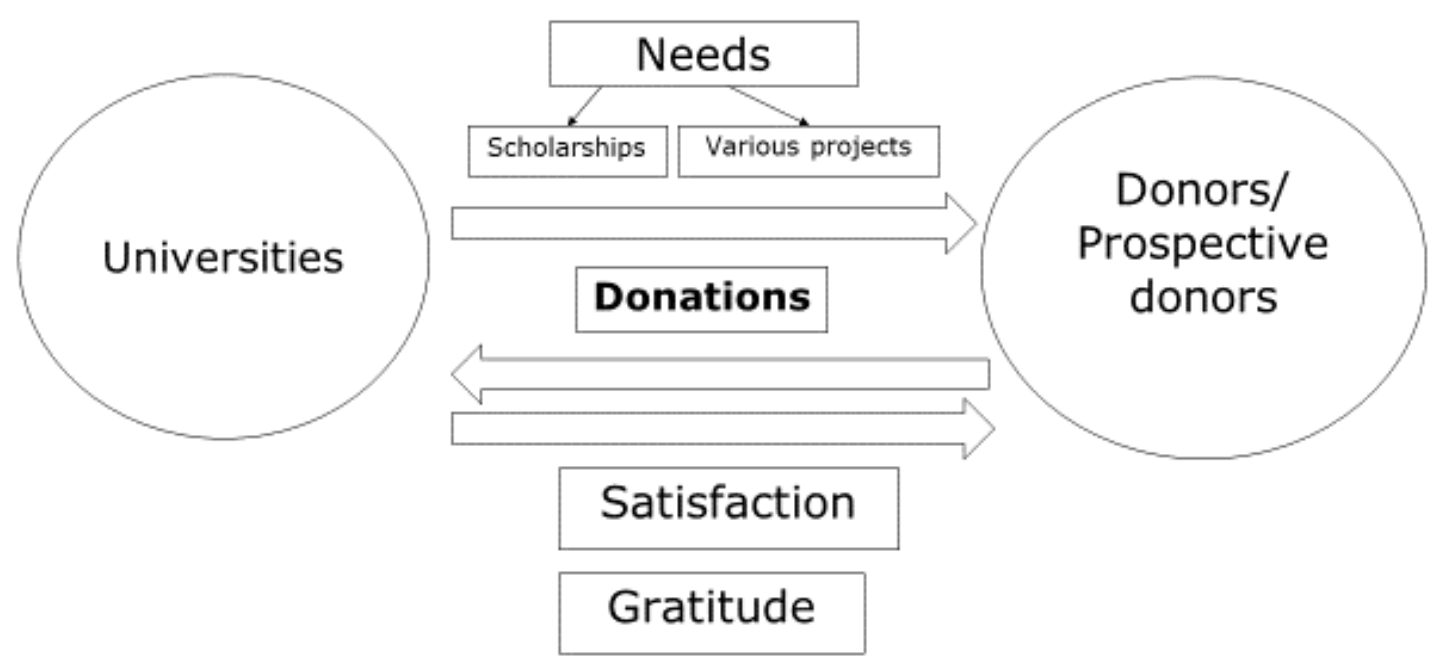

Source: Chadwick-Jones, 1976

Fig. 1. Social exchange theory

This theory emphasizes that the basis is the economic factor, it is the costs that will determine the extent of the benefits and how this relationship between universities and alumni could evolve in the future (Chadwick-Jones, 1976). An important factor in this theory is the quality of service provided by university to students: quality of education, student support in their studies, career opportunities, socialization opportunities, and university prestige. This is of the utmost importance when universities are addressing the alumni seeking their support. This particular factor will determine the amount and type of donations in the short and long term (Lesly and Ramey, 1988). At the same time, researchers believe that the tendency of graduates to be more open to recompensing their universities is most closely linked to the previous civic participation experiences (Weerts, Cabrera, Sanford, 2010).

In turn, the conceptual model puts forward two axioms: (1) motivated graduates are willing to participate in university activities; (2) motivated alumni are willing to recommend others to participate in university activities.

The other part of this model that affects the motivation of alumni is the level of graduate satisfaction and the quality of the university in the eyes of the alumni. This model puts forward the following hypotheses for testing: (1) the degree of satisfaction of the alumni corresponds to the desire to participate in university's activities; $(2)$ the degree of satisfaction of the alumni corresponds to the wish to recommend others to participate in the university activities; (3) the level of university image quality as perceived by alumni corresponds to their desire to participate in university activities; (4) the level of university image quality as perceived by alumni corresponds to the wish to recommend others to participate in university activities. The results of the study show that those alumni whose level of satisfaction with the perceived level of university image quality and themselves as alumni are the factors that promote recommending others to participate in the university activities, as well. To achieve this, collaboration between academic and administrative staff is required. 


\section{Conceptual model}

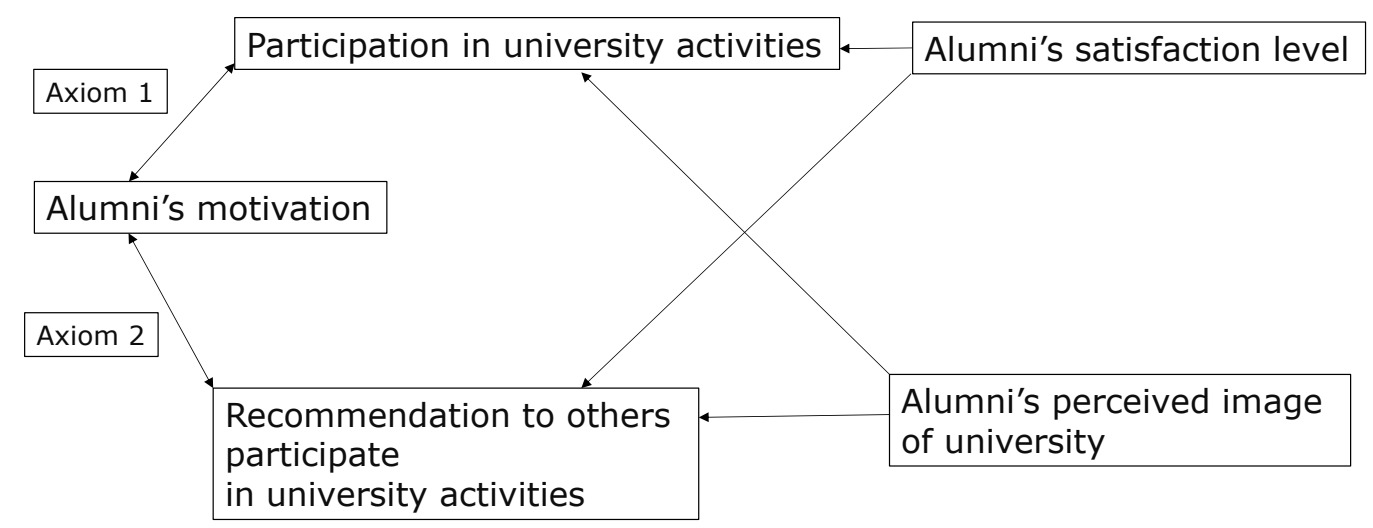

Source: Pedro \& Andraz, 2019

Fig. 2. Conceptual model

It is also imperative to consider the following aspect of work with alumni: the forms of cooperation with alumni need to be diversified. Different and corresponding approaches to communication should be established with alumni representing different age groups. Those, who have graduated from university two years ago, would have an entirely different attitude towards their alma mater than the ones who completed their studies eight years ago (Pedro, Pereira, Carrasqueira, 2018).

When asked whether the generosity depends on gender, a study conducted at a small art college over 31 years brought a conclusion that women are more generous donors than men. Gender, age, nationality and income level were used as criteria. Researchers found that women were not only more generous, but they also donated more frequently than men. This indicates that women are more likely to enter into long-term relationships - in this case, donating small amounts, but more often. Men, on the other hand, in their wish for more recognition and attention, donate seldom, but much greater amounts. Not only do women donate smaller amounts, but they also donate to multiple purposes, to several charities. Fundraising organizations should take these factors into account when developing their fundraising strategies. For example, these results indicate that annual donations for a specific purpose are better suited to encourage women to donate, whereas men should be invited to donate to a "special campaign" to make their donation more unique and significant (Dvorak and Toubman, 2013).

In a study of alumni who have become executives, researchers conclude that senior executives with higher position and income are more likely to give donations. For them, it is a decisive factor that their family and friends find out about their donation. University success stories are also a notable criterion. It makes a difference for high-level professionals to donate to a successful university that has clear development goals and ambitions for even more significant achievements. This criterion indicates that the patron wants to be a part of something significant and successful. Research shows that the wealthier regions receive higher donations, as opposed to the regions with lower economic performance. Researchers also point out that the donating alumni have lower ambitions regarding receiving the university's recognition than the donors who have not graduated 
from the supported university. In the United States, the accomplishments of university sports teams carry weight with alumni. However, researchers point out that universities should note that only an equal balance between academic goals and sports is the right tactic for fundraising. This would enable universities to reach out to a larger number of existing and potential donors (Wunnava, Okunade, 2013).

Universities should encourage not only alumni but also their staff to donate. Researchers have studied the willingness to donate among the following target groups: administrative staff consisting of alumni, administrative staff whose members have not graduated from the respective university, academic staff consisting of alumni, and academic staff whose members have not graduated from the respective university. The status of alumni among both administrative and academic staff is not an important consideration. This does not affect the amount of the donated sum, while impacts the frequency of donations. This undermines the assumption that during the study years, which are largely the years of personality development, the time spent with fellow students and university lecturers, as well as administrative staff, creates strong links that are remembered for lifetime. From amongst the employees, it is the higher-income academic staff who donate to the university, whether or not they have graduated from it. It is perhaps this close connection which makes the alumni donors, who are employees, the weaker contributors. Possibly, a sense of identity characterised by belonging to university has taken too long to form and thus diminishes the motivation to donate. The study indicates that calling for donations from an alumnus, an alumnus - employee, who is one and the same person, is a mistake. Sufficiently detailed databases must be maintained to enable fundraisers to apply only one identity to a particular person to minimize confusion when receiving, for example, two or three calls for donations at a time. Donors usually choose a convenient, recognizable donation goal, most often donating to the needs of their faculty (Borden, Shaker, Kienker, 2014).

By visualizing the relationship between the alumni and their alma mater, the researchers find that the following factors work in this relationship: "the image of education", "the image of communications", and satisfaction with the social and academic environment. This set of factors answers the researchers' question: "Which factors are important and which are decisive in a successful relationship?" Relationships can be considered successful if the response of alumnus to the question "If it were possible, would you choose the same university and study programme once again?" is affirmative. A sense of belonging comes from the pride of one's university and shared values. The desire to recompense your alma mater is reinforced by a verbal or written statement by alumni, calling to donate permanently and as required by the university. Strong alumni-centric communication from the university administration and lecturers is needed to achieve such statement from the alumni community or individuals. In communication with alumni, the university must be like a "loving mother" and alumni - as "beloved children." Universities must harness the potential of alumni to attract future students. They could be guides of university tours, participate as speakers in introductory seminars, and share information on studying in their alma mater with family members and among friends. The alumni should be seen by the university as equal partners in university development (Pedro, Pereira \& Carrasqueira, 2018).

The donation activity of alumni is dependent on the university's invitations to give to one of the fundraising campaigns. One of the goals of the University of Latvia Foundation is to work with the those who have received the scholarships of the University of Latvia Foundation's patrons and have already become alumni. Figure 3 below clearly shows that between 2012 and 2014, there is a 
significant donor activity among alumni. This can be explained with two large-scale donation campaigns that have been launched in 2012: "The University of Latvia Organ Restoration Campaign" and "Business Incubator Business Idea Foundation".

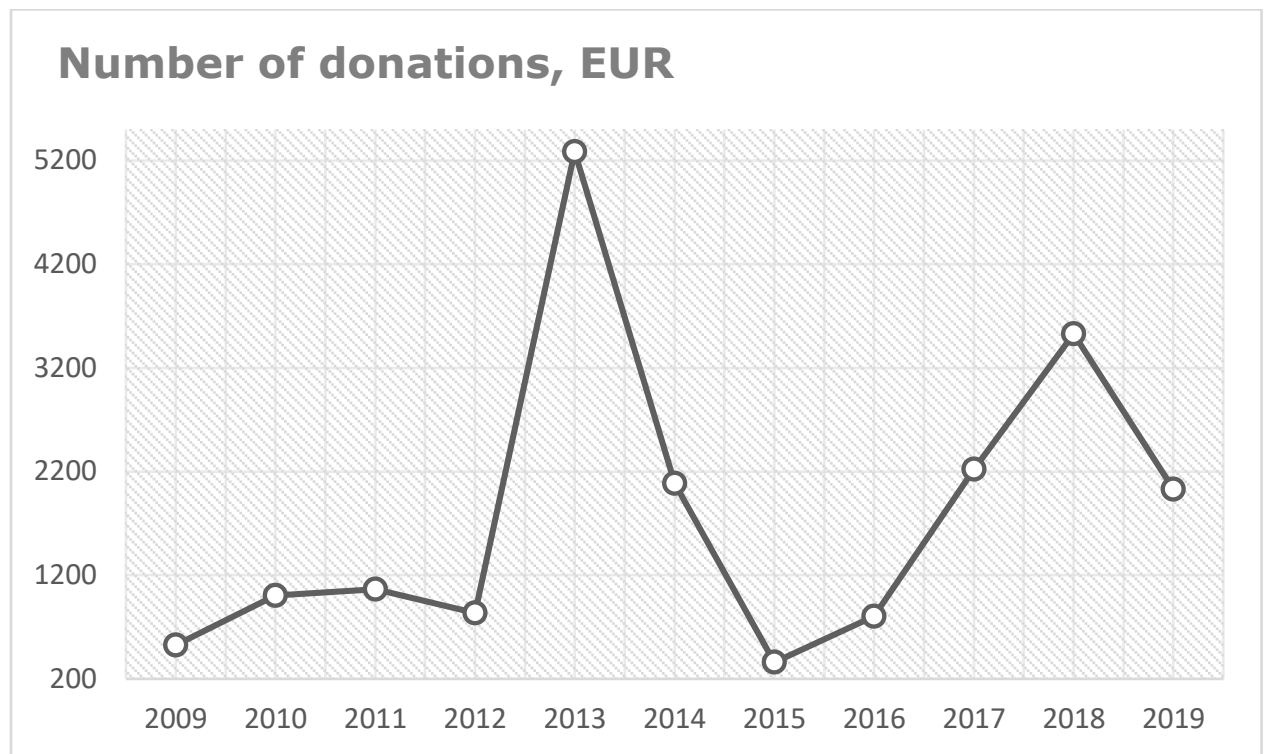

Source: Foundation of the University of Latvia data, prepared by authors

Fig. 3. Number of donations, EUR

The fundraising principles of the UL Foundation require that after large-scale fundraising campaigns there must be an intermission to avoid tiring donors. That is why the amount of donations is lower in 2015 and 2016.

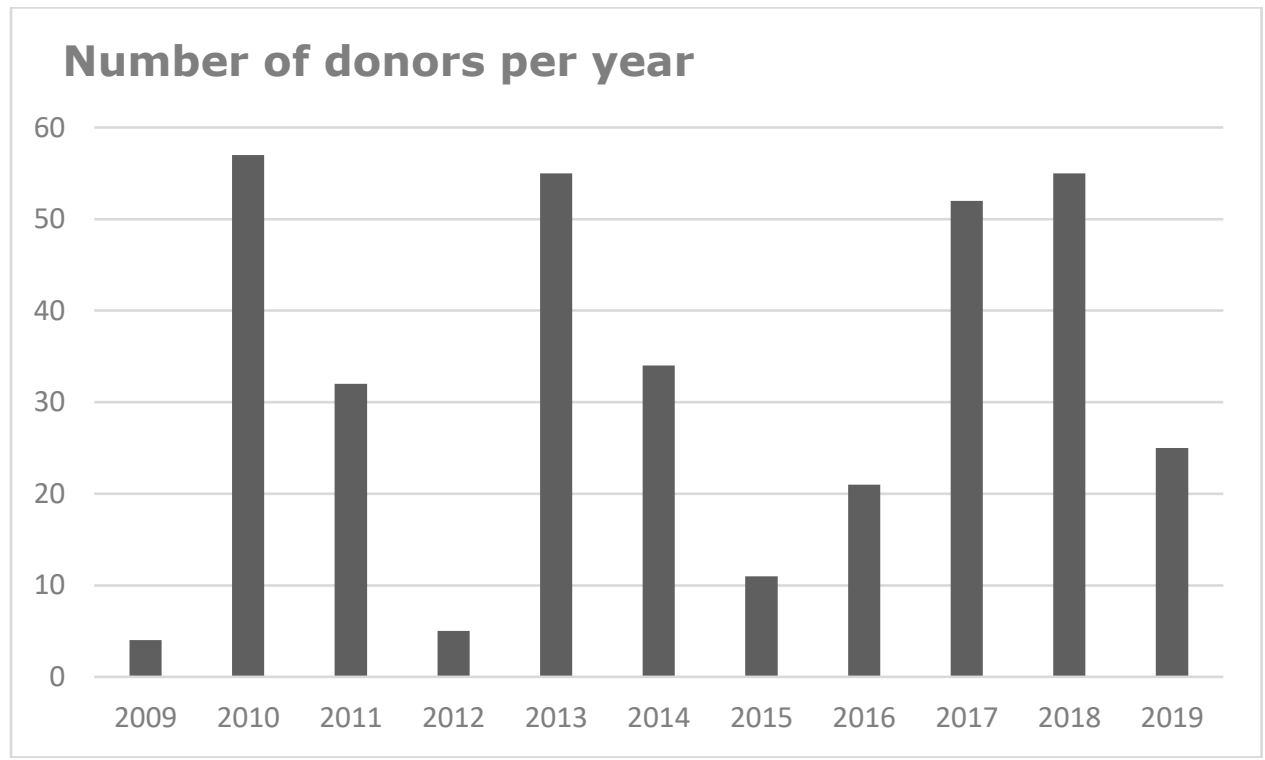

Source: Foundation of the University of Latvia data, prepared by authors

Fig. 4. Number of donors

Of the 1980 scholarship recipients supported by the patrons of the UL Foundation, 243 scholars who are now alumni have donated at least once. Figure 4 above shows that the first major inflow of donors has taken place in 2010, which is substantiated by the fact that the $90^{\text {th }}$ anniversary of the University of Latvia was celebrated in the academic year of $2009 / 2010$, and alumni - the former scholarship recipients - readily responded to the invitation to donate to the $90^{\text {th }}$ anniversary of the University of Latvia. In 2013, the aforementioned fundraising campaigns were held, whereas donors' activity in 2017 and 2018 was brought about by changes in the UL Foundation's fundraising strategy. From then onward it stipulates that every former UL Foundation's patron scholarship recipient who 
is an alumnus and has donated at least once, should be addressed once a year to donate to a topical project of the University of Latvia. This would most certainly be called a "vote of loyalty". The fundraising strategy of the University of Latvia Foundation sets down a principle: every donation is important, regardless of its size. The exception was 2019, when due to the questioning of the election of the University of Latvia rector at the Republic of Latvia Cabinet of Ministers, the former scholarship holders - alumni were not addressed.

Data collected by the UL Foundation prove that fundraising campaigns are an effective fundraising tactic. The introduction of a "loyalty vote" in the fundraising strategy of the UL Foundation is a longterm fundraising tactic, habituating the current donors to repeat their donation every year.

\section{Conclusion, proposals, recommendations}

1) The results of the study confirm all four hypotheses advanced at the outset. Motivated university alumni are good partners of any university in successful fundraising and attracting prospective students. Universities need to be prepared for equal, peer-to-peer communication, including listening to criticism and proposals for change.

2) Universities should develop well-considered collaborative models with alumni by offering them varied opportunities for collaboration, including donations of money, contributions in-kind, pro bono, and giving their time as volunteers.

3) Universities should consider the gender, marital status, income level and public status of alumni, when establishing a cooperation or planning fundraising campaigns. Fundraising campaign strategies must have a diverse offer of collaboration adjusted to the different gender, age and wealth level groups.

4) Beyond the alumni, the universities should focus their fundraising activities also on those who are not their graduates but are, instead, university staff and members of public loyal to the university. Sometimes those who are not alumni, but passionately support a certain direction undertaken by the university, will be the ones who will make significant donations to develop that direction.

\section{Acknowledgments}

The preparation of the current paper was supported by the National Research Programme 5.2. project "INTERFRAME-LV".

\section{Bibliography}

1. Alumni Relations Task Force (2004). University of Virginia. Available at https://bov.virginia.edu/system/files/public/meetings/\%2704\%20FEB\%20EXT\%20AFFRS\%20COMM\%20MI NS.pdf, accessed on 10.03.2020.

2. Astin, A. W., Sax, L. J. and Avalos, J. (1999). Long-term Effects of Volunteerism During the Undergraduate Years. The Review of Higher Education, 22(2), pp. 187-202.

3. Borden, V. M. H., Shaker, G. G., Kienker, B. L. The Impact of Alumni Status on Institutional Giving by Faculty and Staff. Research in Higher Education, Vol. 55, No. 2, pp. 196-217.

4. Brittingham, B., Pezzullo, T. (1990). The Campus Green: Fund Raising in Higher Education; ASHE-ERIC Higher Education Report 1; ASHE-ERIC Higher Education Reports; The George Washington University: Washington DC, USA.

5. Burke, K. E. (1988). Institutional Image and Alumni Giving. Unpublished doctoral dissertation, University of Maryland, College Park, MD.

6. Caboni, T. C. and Proper, E. (2008). Dissertations Related to Fundraising and Their Implications for Higher Education Research. Paper presented at the Annual Meeting of the Association for the Study of Higher Education, November 10, 2007.

7. Cabrera, A. F., Weerts, D. J., and Zulick, B. J. (2005). Making an Impact with Alumni Surveys. In: D. J. Weerts and J. Vidal (eds.), Enhancing alumni research: European and American perspectives. New Directions for Institutional Research, No. 126. San Francisco: Jossey-Bass. pp. 5 - 17. 
8. Council for Aid to Education. (2008) Contributions to Colleges and Universities up by 6.3 Percent to $\$ 29.75$ Billion. Available at http://philanthropynewsdigest.org/news/contributions-to-colleges-universities-up-6.3percent-in-2007-survey-finds, accessed on 10.03.2020.

9. Chadwick-Jones, J. K. (1976). Social Exchange Theory: Its Structure and Influence in Social Psychology. London: Academic Press, pp. 431.

10.Cutlip, S. M. (1990). Fundraising in the United States, Its Role in America's Philanthropy. Transaction Publishers: New Brunswick, NJ, USA.

11. Deloitte (2011). Making the Grade 2011: A Study of the Top 10 Issues Facing Higher Education Institutions.

12. Dvorak, T., Toubman, S. R. Are Women More Generous than Men? Evidence from Alumni Donations. Eastern Economic Journal, Vol. 39, No. 1, pp. 121-131.

13. Johnstone, D. B. University Revenue Diversification Through Philanthropy: International Perspectives. Available at http://www.intconfhighered.org/BruceJohnstone.pdf, accessed on 10.03.2020.

14. Fogg, P. (2008). How Colleges Use Alumni to Recruit Students. Chronicle of Higher Education, 54(34), B13.

15. Kozobarich, J. (2000). Institutional Advancement. New Directions for Higher Education, pp. 111, 25-34.

16. Leslie, L. L. and Ramey, G. (1988). Donor Behavior and Voluntary Support for Higher Education Institutions. The Journal of Higher Education, 59(2), pp. 115-132.

17. Potter, W. (2003). Citizen Lobbyists: In Tight Budget Times, Colleges Recruit and Train Alumni, Parents, and Even Students as Advocates. Chronicle of Higher Education, 49(33), A24.

18. Pedro, I. M., Pereira, L. N., Carrasqueira, H. B. (2018). Determinants for the Commitment Relationship Maintenance Between The Alumni and The Alma Mater. Journal of Marketing for Higher Education, Vol. 28, No. 1 , pp. $128-152$.

19. Penner, L. A. (2002). Dispositional and Organizational Influences on Sustained Volunteerism: An Interactionist Perspective. Journal of Social Issues, 58(3), pp. 447-467.

20. Weerts, D. J., Cabrera, A. F. and Sanford, T. (2010). Beyond Giving: Political Advocacy and Volunteer Roles of College Alumni. Research in Higher Education, pp. 346-365.

21. Weerts, D. J. (1998). Back on track: Seven Strategies to Get Your Alumni Board Moving Again. CASE Currents, pp. 24, 35-37.

22. Weerts, D. J. and Ronca, J. M. (2008). Characteristics of Alumni Donors Who Volunteer at Their Alma Mater. Research in Higher Education, 49(3), pp. 274-292.

23. Wunnava, P. V., Okunade, A. A. (2013). Do Business Executives Give More to Their Alma Mater? Longitudinal Evidence from a Large University. The American Journal of Economics and Sociology, Vol. 72, pp. 761-778. 